Research Article

\title{
Experimental and Techno-Economic Analysis of Solar-Geothermal Organic Rankine Cycle Technology for Power Generation in Nepal
}

\author{
Suresh Baral iD \\ School of Engineering, Pokhara University, Pokhara-30, Nepal \\ Correspondence should be addressed to Suresh Baral; sbaral.sb@gmail.com
}

Received 6 May 2019; Accepted 13 August 2019; Published 8 September 2019

Academic Editor: Jegadesan Subbiah

Copyright ( 2019 Suresh Baral. This is an open access article distributed under the Creative Commons Attribution License, which permits unrestricted use, distribution, and reproduction in any medium, provided the original work is properly cited.

\begin{abstract}
The current research study focuses on the feasibility of stand-alone hybrid solar-geothermal organic Rankine cycle (ORC) technology for power generation from hot springs of Bhurung Tatopani, Myagdi, Nepal. For the study, the temperature of the hot spring was measured on the particular site of the heat source of the hot spring. The measured temperature could be used for operating the ORC system. Temperature of hot spring can also further be increased by adopting the solar collector for rising the temperature. This hybrid type of the system can have a high-temperature heat source which could power more energy from ORC technology. There are various types of organic working fluids available on the market, but R134a and R245fa are environmentally friendly and have low global warming potential candidates. The thermodynamic models have been developed for predicting the performance analysis of the system. The input parameter for the model is the temperature which was measured experimentally. The maximum temperature of the hot spring was found to be $69.7^{\circ} \mathrm{C}$. Expander power output, thermal efficiency, heat of evaporation, solar collector area, and hybrid solar ORC system power output and efficiency are the outputs from the developed model. From the simulation, it was found that $1 \mathrm{~kg} / \mathrm{s}$ of working fluid could produce $17.5 \mathrm{~kW}$ and $22.5 \mathrm{~kW}$ power output for R134a and R245fa, respectively, when the geothermal source temperature was around $70^{\circ} \mathrm{C}$. Later when the hot spring was heated with a solar collector, the power output produced were $25 \mathrm{~kW}$ and $30 \mathrm{~kW}$ for R134a and $\mathrm{R} 245 \mathrm{fa}$, respectively, when the heat source was $99^{\circ} \mathrm{C}$. The study also further determines the cost of electricity generation for the system with working fluids R134a and R245fa to be $\$ 0.17 / \mathrm{kWh}$ and $\$ 0.14 / \mathrm{kWh}$, respectively. The levelised cost of the electricity (LCOE) was $\$ 0.38 / \mathrm{kWh}$ in order to be highly feasible investment. The payback period for such hybrid system was found to have 7.5 years and 10.5 years for R245fa and R134a, respectively.
\end{abstract}

\section{Introduction}

Renewable energy sources such as solar, biomass, geothermal, and hydro are the alternative energy sources for power generation. Due to excessive use of fossil fuel for power generation, the environment is polluted day by day thereby affecting and threatening living and human beings. Therefore, the renewable energy should be deployed and implemented in every aspects of power production. According to International Energy Agency (IEA), renewable energy will have the fastest growth in the electricity sector which provides almost $30 \%$ of power demand in 2023 globally. During this period, solar PV which is one of the renewable energy technologies is forecasted to meet more than $70 \%$ of the global electricity generation followed by wind, hydro, and bioenergy [1]. In Nepal, the scenario is quite different than others globally. The hydroelectric plant generates all the power needed for the country in a large scale. The solar energy has not been fully utilized for power generation apart from off-grid and some minigrid systems. Similarly, the wind and bioenergy power generation is very fewer in operations. On the other hand, a geothermal source is not exploited till now in Nepal for power generation. Even there is not much literature regarding the potential of power production from such source in the country. The solar energy source such as solar PV has been widely used all over the world due to low 


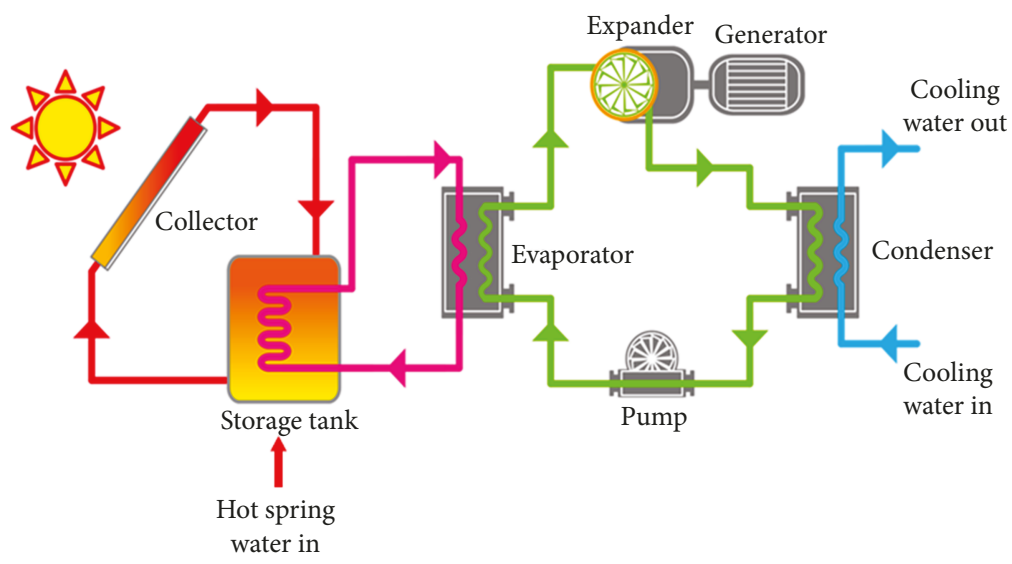

FIGURE 1: Hybrid solar-geothermal ORC system.

cost and technological advancement in that field. In a developed country, the grid connection solar PV has been installed for power production, but in developing countries such as Nepal, solar PV is installed in a rooftop of rural and urban households. Another category of solar energy utilization technology is concentrating solar power (CSP). This technology is primarily used in a large power plant for electricity generation.

Nepal lies on the good solar belt making the application of solar power attractive. In Nepal, it has been estimated that there is more than 6.5 hours of sunshine per day with approximately 300 days with the average isolation lying between 4 and $5 \mathrm{kWh}$ per square meter per day [2-4]. Due to the exponential growth of organic Rankine cycle (ORC) technology installation and waste heat recovery utilization, the solar ORC technology installation in Nepal represents a strong motivation for investments in renewable energies especially the solar energy.

The use of solar energy for generating electrical power by utilizing organic compounds such as the working fluid in the solar Rankine cycle system is a new concept and is expected to be popular in Nepal. Solar organic Rankine cycle (ORC) technology is similar to the conventional steam Rankine cycle, but its working fluid is either pure or a mixture of organic compounds instead of water. Solar ORC technology has three main units [5, 6]: (1) solar thermal conversion unit, (2) ORC unit, and (3) power block. The working principle of this technology is as follows. The solar energy is collected by an array of solar collectors, each of which focuses the incoming sunlight onto a pipe located at the trough focal point, where a heat transfer fluid passes through a heat exchanger and transfers its heat to the working fluid of the ORC. This working fluid, when expanded, drives the ORC expander that is coupled to an electrical generator to produce electricity. The working fluid after passing through the expander goes to a condenser to transfer any remaining heat to the surrounding air/water, which causes the fluid to recondense into a liquid. The resulting liquid is then returned to the evaporator again through a pump. In this way, the cycle is completed. Figure 1 shows the working principle of the hybrid ORC system.
The stand-alone hybrid solar-geothermal ORC plant could be one of the appropriate technologies for the rural areas of Nepal for electrical power generation. Rural areas of Nepalese location lack grid connection with the mainline of electricity. So this study could be of significant importance in context to Nepal. Besides, there are numerous hot springs and these are utilized for recreational and skin treatment purposes. Typically, the natural hot spring temperature in Nepal ranges from $42^{\circ} \mathrm{C}$ to $73^{\circ} \mathrm{C}$ as various literature shows $[7,8]$. This proposed study helps in estimating the feasibility of the low-temperature hot spring temperature utilization through the concept of organic Rankine cycle technology. Furthermore, Nepal has an average solar radiation of $4.7 \mathrm{kWh} / \mathrm{m}^{2}$ per day. So this solar energy can also be harnessed when implemented as a hybrid system.

The solar-geothermal (hot spring) ORC system would be innovation development in terms of scientific and technological aspects. The proposed research could be beneficial not only to Nepal but also to the entire world in the low-grade heat utilization through the ORC system.

Several scientific articles regarding hybrid solargeothermal ORC technology include theoretical and experimental studies. In addition, the application of ORC technology includes biomass, geothermal, and solar energy utilization. In this study, the main focus of the ORC technology application is the hybrid solar-geothermal system. Heberle et al. [9] studied a concept on a solar thermal retrofit unit for geothermal ORC power plants in Turkey. The result obtained was increased in $4.5 \%$ of annual electricity generation compared with the stand-alone geothermal power plant. Astolfi et al. [10] analyzed a geothermal-based ORC system when combined with the concentrating solar power system. The authors reported that introduction of a solar parabolic trough field resulted in an increase in power production. Besides, an economic analysis was performed in order to obtain levelised cost of electricity for such hybrid system. The estimated LCOE was €145-280/MWh. Similarly, Shu et al. and Yu et al. $[11,12]$ proposed a thermodynamic evaluation and techno-economic evaluations for a novel cascade ORC system for different working fluids. It was estimated that the best economic value for the electricity 
production from the C-ORC system was found to be $\$ 0.27 / \mathrm{kWh}$.

Another study investigated by Ghasemi et al. [13] developed a model for the existing ORC which utilizes a geothermal source and has a model validated with 7200 operation data collected in one year. The results showed that the hybrid solar and geothermal plant yields 3.4\% higher for second law efficiency as compared to the individual geothermal and solar system. Similarly, Bassetti et al. [14] modeled a hybrid geothermal-concentrating solar power plant integrated with solar thermal energy storage (TES) and showed that such unit enabled a $19 \%$ increment in an annual energy production; therefore, the study concluded that a hybrid plant with the addition of a TES unit can be highly beneficial for the system's efficiency. There are several other models such as the one developed by Ayub et al. [15] that suggested that there would be improvement in the net power output from 5.5\% to $6.3 \%$. Furthermore, the analysis revealed that the levelised cost of electricity by the hybrid system can be decreased by $2 \%$ as compared to the stand-alone geothermal system. Song et al. [16] simulated a solar-geothermal energy-coupled ORC system technology for finding the net thermal efficiency of the system. By the simulation results, the thermal efficiency of the coupled system is $11.21 \%$ higher as compared to the single air-cooled geothermal ORC system.

Various articles described only the solar-geothermal ORC system for the thermal efficiency performance. There is not any literature which describes the potential of hot spring for power generation by the ORC technology. When the hot spring is coupled with a solar thermal collector, the temperature of the hot spring will be increased. This increase in temperature is enough to operate the ORC system. Therefore, the current research could address the potential for power generation by hot springs where the source temperature is enough to operate the ORC plant in Nepalese context.

The main objective of the research is to study the feasibility of electrical power generation by the concept of stand-alone hybrid solar-geothermal organic Rankine cycle (ORC) technology in the Bhurung Tatopani area of Myagdi District, Nepal. The specific objectives for the research are as follows: (a) to determine the temperature of natural hot spring geothermal resources which can be utilized for evaporation of organic working fluids, (b) to measure the temperature of the solar collectors' hot water which will enhance the ORC system for running for higher time after sunset, and (c) to estimate the economic aspect of this technology in context to a Nepalese economic scenario.

\section{Materials and Methods}

In order to study the feasibility of stand-alone hybrid solargeothermal ORC system technology, an experiment and thermodynamic models have been developed and proposed for characterizing the performances of the system. Various methods that have been adopted in this study are as follows:

2.1. Preliminary Investigation of a Geothermal Hot Spring Site. In the preliminary geothermal hot spring site investi-

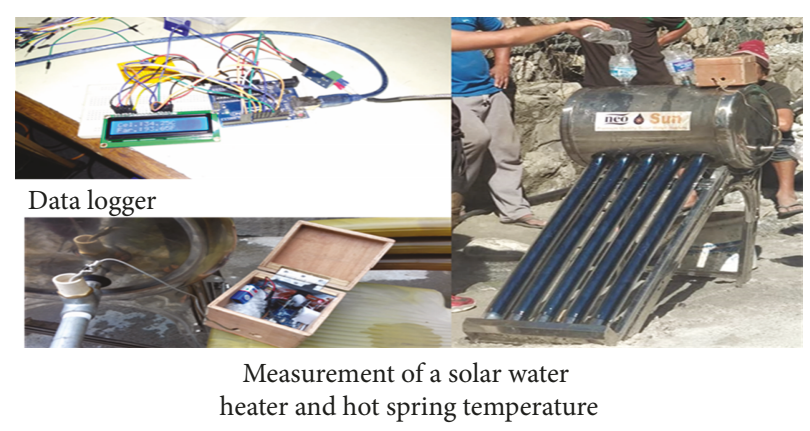

Figure 2: Experimental setup in the investigated location.

gation, the following assessment had been conducted in Bhurung Tatopani.

(i) Estimated the quality of hot water to determine whether it contains contamination or not

(ii) Estimated the discharge of natural hot water along with the stream channel

(iii) Assessed other hot springs' geothermal activity around the catchment area

2.2. Experiments. In the experimental analysis, the temperature of the hot spring was measured along with the flow rate. The hot spring water was stored in the storage tank. The stored hot water temperature was measured for knowing whether the temperature could be able to run the ORC system or not. Furthermore, the duration of constant hot water temperature was measured throughout the two different seasons (winter and summer).

Similarly, in the same experimental setup, the solar collector's hot temperature water was pumped into the storage tank. The temperature of the stored hot water was measured. Later, the stored hot water was being mixed with hot spring. The measured temperature after mixing helped to estimate the capability for evaporation of the working fluid. The measured temperature was applied in the developed model. The built model predicts the power output from the hybrid stand-alone solar-geothermal ORC system. Figure 2 shows the experimental setup for measuring the temperature.

2.3. Development of Models for the System. For the development of models, the desired thermodynamic properties of the ORC working fluid at different state points should be known. The thermodynamic properties of an ORC working fluid can be described best by the energy equation and calculated using the software known as Energy Equation Solver (EES). Therefore, all the thermodynamic properties of ORC working fluids in this study will be obtained using the academic version of the software EES. Likewise, for solar resource assessment information, the data from NASA and NREL were taken. This information can be easily available in their websites. After obtaining global horizontal irradiance (GHI) and DNI, the heat source temperature to run the ORC system can be estimated. Moreover, the thermodynamic analysis in a steady state shall also be conducted for each 
thermal conversion unit and ORC unit. Various assumptions for modeling are as follows:

(1) The calculation is based on steady-state conditions

(2) The pressure drops in the heat exchangers are neglected

(3) The heat losses from the various components are assumed to be negligible

2.3.1. ORC Component Models. The general expressions for the energy balances of any steady state that are applied in each of the system components can be expressed as

$$
\begin{gathered}
\sum \dot{m}_{\text {in }}=\sum \dot{m}_{\text {out }}, \\
\dot{Q}-\dot{W}+\sum \dot{m}_{\text {in }} h_{\text {in }}-\sum \dot{m}_{\text {out }} h_{\text {out }}=0,
\end{gathered}
$$

where subscripts in and out represent the inlet and outlet, respectively, $\dot{m}$ and $h$ represent the mass flow rate and specific enthalpy, respectively, of the streams of the system working fluid, and $\dot{Q}$ and $\dot{W}$ represent the heat transfer and work transfer crossing the component boundaries, respectively. The ORC components in the system consist of a pump, an expander, an evaporator, and a condenser. The main governing equations for the development of the models are described below:

$$
\text { Pump: } W_{\mathrm{p}}=\frac{\bar{v}_{\mathrm{p}}\left(P_{\mathrm{o}}-P_{\mathrm{i}}\right) \times \dot{m}_{\mathrm{f}}}{\eta_{\mathrm{p}}},
$$

where $P_{\mathrm{o}}$ and $P_{\mathrm{i}}$ denotes the pressure at the outlet and inlet of the pump, respectively.

$m_{\mathrm{f}}, \eta_{\mathrm{p}}$, and $v_{\mathrm{f}}$ are the mass flow rate of the working fluid, efficiency of the pump, and specific volume of the fluid, respectively.

$$
\text { Evaporator: } Q_{\text {eva }}=\dot{m}_{\mathrm{f}}\left(h_{\mathrm{i}}-h_{\mathrm{o}}\right) \text {, }
$$

$\mathrm{Nu}=h D_{\mathrm{h}} / K$ is the Nusselt number, $\operatorname{Re}=\rho v D_{\mathrm{h}} / \mu$ is the Reynolds number, $h$ is the convection heat transfer coefficient, $\rho$ is the density of material, $v$ is the velocity, $\mu$ is the viscosity of the material, and $D_{\mathrm{h}}$ is the hydraulic diameter of the heat exchanger.

$$
\text { Expander: } W_{\exp }=\dot{m}_{\mathrm{f}}\left(h_{\mathrm{i}}-h_{\mathrm{o}}\right),
$$

where $h_{\mathrm{i}}$ and $h_{\mathrm{o}}$ are the enthalpy at specific pressure and temperature at the inlet and outlet of the expander, respectively.

$$
\text { Condenser: } Q_{\text {con }}=\dot{m}_{\mathrm{f}}\left(h_{\mathrm{i}}-h_{\mathrm{o}}\right) \text {, }
$$

where $h_{\mathrm{i}}$ and $h_{\mathrm{o}}$ are the enthalpy at specific pressure and temperature at the inlet and outlet of the condenser.
The abovementioned governing equations are based on basic laws of thermodynamics as presented by the authors [17].

2.3.2. Solar Collector Model. The solar radiation data accounts for beam, diffuse, and reflected components of the solar irradiation. The model consists of computation of clear sky global irradiation on a horizontal surface and calculation of clear sky index, diffuse, and beam components on inclined surfaces.

The solar collector can be modeled for two different types of collector. They are non-concentrating and concentrating collectors. In these models' development, the evacuated tube and parabolic trough technology collectors will be taken for non-tracking and tracking cased global and direct beam irradiance data. The governing equation for the solar collector is as follows [18]:

$$
\eta=C_{\mathrm{o}}-C_{1}\left(\frac{T_{\mathrm{c}}-T_{\mathrm{a}}}{I_{\mathrm{sol}}}\right)-C_{2} \frac{\left(T_{\mathrm{c}}-T_{\mathrm{a}}\right)^{2}}{I_{\text {sol }}} .
$$

Here, $C_{\mathrm{o}}, C_{1}$, and $C_{2}$ are collector constants and $T_{\mathrm{c}}$ and $T_{\mathrm{a}}$ are the mean collector temperature and ambient temperature, respectively.

The area of the solar collector is calculated using the collector energy balance equation which is as follows:

$$
\dot{m}_{\mathrm{c}} \cdot\left(h_{\mathrm{o}}-h_{\mathrm{i}}\right)=G_{\mathrm{b}} \cdot \eta_{\mathrm{c}} \cdot A_{\mathrm{c}},
$$

where $\eta_{\mathrm{c}}, A_{\mathrm{c}}$, and $G_{\mathrm{b}}$ are the collector efficiency, area of the collector, and global radiation on the surface, respectively. The net solar ORC efficiency of the system is given by the following equation:

$$
\eta_{\text {SORC }}=\eta_{\mathrm{c}} \times \eta_{\mathrm{ORC}}
$$

2.4. Techno-Economic Analysis of the Hybrid ORC System. In another part of the research, the economic analysis for the hybrid system was conducted which included calculation of the net present value (NPV), payback period, internal rate of return (IRR), benefit-cost ratio (BC ratio), and levelised cost of electricity production (LCOE). The technoeconomic analysis of the hybrid solar-geothermal ORC has the governing equations which are shown in Table 1.

\section{Results and Discussion}

The investigated site was on the location (longitude: 83.61 and latitude: 28.49) at an elevation of $3004 \mathrm{~m}$ of Myagdi District. There are various hot springs in Nepal, but the Tatopani hot spring was one of the sites where the experimental work has been conducted. The site had not been contaminated, and the location for experiment was perfect. There was no any debris near the site (source of hot spring). During the months of February and March, the Kaligandaki River has not affected the heat source site, but the effect can be seen when it was rainy season during July. It was observed that the hot spring was used as recreational purposes in that location. The hot spring was pumped from the source in the pond 
TABLE 1: Governing equations for economic analysis [21].

\begin{tabular}{|c|c|c|}
\hline Economic parameters & Governing equations & Representation \\
\hline Annual equivalent cost (AEC) & $\mathrm{AEC}=\sum_{C=1 N} \frac{\mathrm{IC}_{C} \times(i)}{1-(1+i)^{-n}}$ & \multirow{5}{*}{$\begin{array}{l}\text { IC represents the capital cost, } \\
n \text { is the system life period, } \\
i \text { is the interest rate, } B \text { and } \\
C \text { denote the benefit and cost at } \\
\text { the end of the period, respectively. }\end{array}$} \\
\hline Net present value (NPV) & $\mathrm{NPV}=B_{t=0}-C_{t=0}=\sum_{j=0}^{n} \frac{B_{t=j}}{(1+i)^{j}}-\sum_{j=0}^{n} \frac{C_{t=j}}{(1+i)^{j}}$ & \\
\hline Benefit-cost ratio (BC) & $\mathrm{BC}=\frac{B_{t=0}}{C_{t=0}}=\frac{\sum_{j=0}^{n}\left(B_{t=j} /(1+i)^{n}\right)}{\sum_{j=0}^{n}\left(C_{t=0} /(1+i)^{n}\right)}$ & \\
\hline Payback period (PB) & $\sum_{j=0}^{\mathrm{PB}} \frac{B_{t=j}}{(1+i)^{j}}=\sum_{j=0}^{\mathrm{PB}} \frac{C_{t=j}}{(1+i)^{j}}$ & \\
\hline Internal rate of return (IRR) & $\sum_{j=0}^{n} \frac{B_{t=j}}{(1+\mathrm{IRR})^{j}}=\sum_{j=0}^{n} \frac{C_{t=j}}{(1+\mathrm{IRR})^{j}}$ & \\
\hline
\end{tabular}

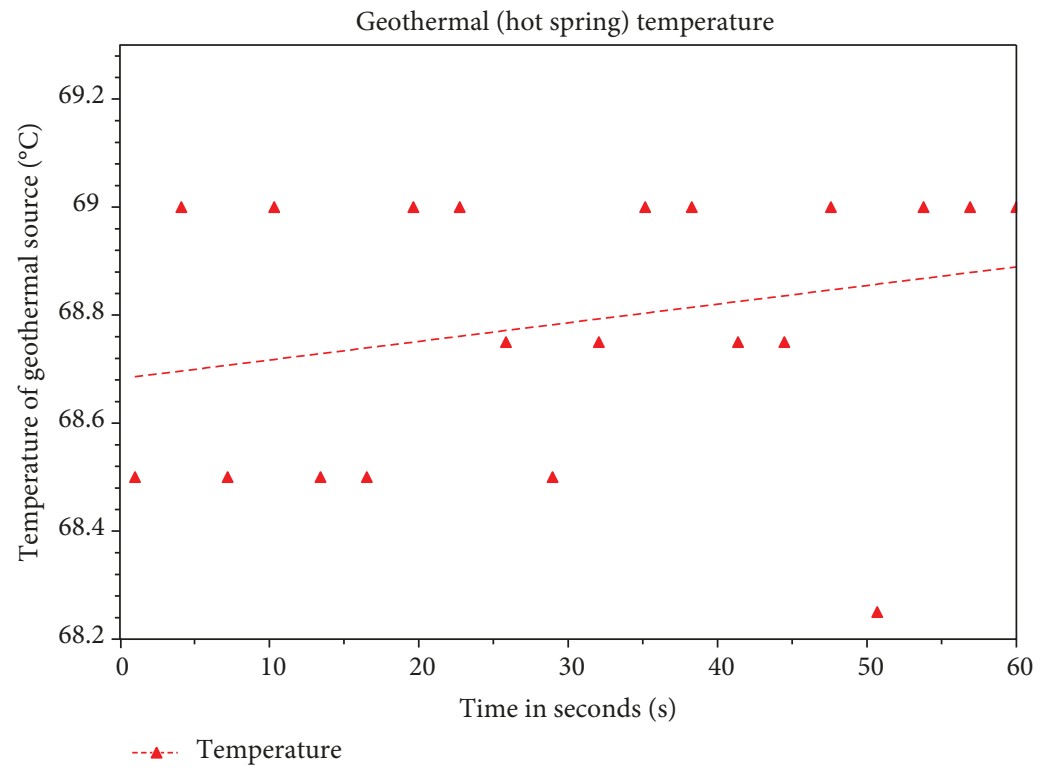

FIgURE 3: Temperature of the geothermal source (hot spring).

for the storage and recreational activities such as bathing and refreshing. The nearby hot springs were quite far from the investigated location. This was the preliminary investigation before conducting the experiment in order to study the feasibility of the power generation by the geothermal source (hot spring) ORC system.

3.1. Experimental Activity Results. After the preliminary investigation of the source of the hot spring in the location, the temperature of the hot spring was measured. The data logger was used for measuring the temperature with thermocouples. The temperature of the source was almost constant through the measurement. The maximum temperature of the Tatopani hot spring was approximately $70^{\circ} \mathrm{C}$ as shown in the measurement. Figure 3 shows the temperature profile of the hot spring on $31^{\text {st }}$ October 2018. The measured temperature was enough to observe the power output of the geothermal ORC system alone with two different organic working fluids (R134a and R245fa) by applying the obtained
TABLE 2: Boundary conditions for the investigated hybrid solargeothermal ORC system.

\begin{tabular}{lcc}
\hline Parameters & Unit & Values \\
\hline Heat added from the source & $\mathrm{kW}$ & $260-428$ \\
Heat source temperature & ${ }^{\circ} \mathrm{C}$ & $70-150$ \\
Evaporating pressure & $\mathrm{Bar}$ & 9 \\
Mass flow rate (R134a/R245fa) & $\mathrm{kg} / \mathrm{s}$ & 1 \\
Pinch point temperature, evaporator & $\mathrm{K}$ & 10 \\
Pinch point temperature, condenser & $\mathrm{K}$ & 10 \\
Condensation temperature & ${ }^{\circ} \mathrm{C}$ & 20 \\
Cooling water temperature & ${ }^{\circ} \mathrm{C}$ & 15 \\
Cooling water pressure & $\mathrm{Bar}$ & 1 \\
Turbine isentropic efficiency & $\%$ & 70 \\
Pump isentropic efficiency & $\%$ & 70 \\
Solar collector efficiency & $\%$ & 70 \\
\hline
\end{tabular}




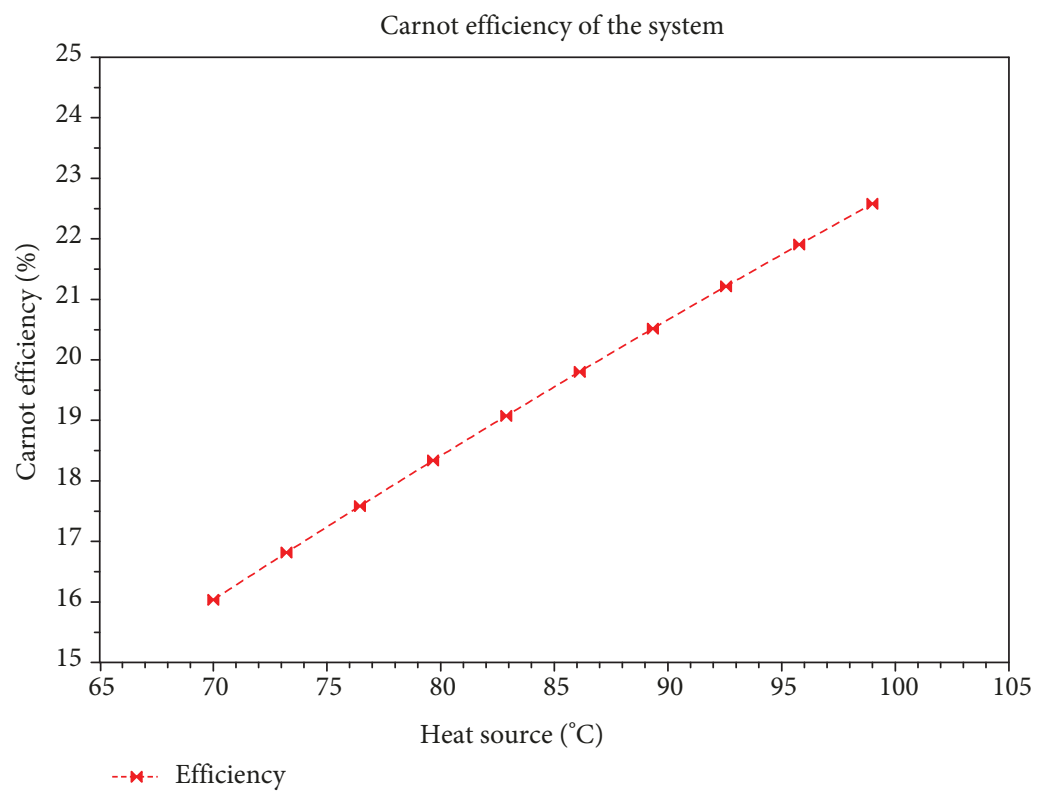

Figure 4: Variation in Carnot efficiency on the effect of the heat source.

data on the developed model. Furthermore, a series of experiment were carried out in order to find the maximum temperature of the hot spring when it was passed into the solar collector. The temperature could be raised to $99^{\circ} \mathrm{C}$ when it was exposed to atmospheric pressure of 1 bar. This final temperature was again applied in the model in order to observe the performance of the system by simulation results with the organic working fluids.

3.2. Simulation Results from the Developed Model. The model of the hybrid solar-geothermal ORC system consists of various main components such as pump, evaporator, expander, condenser, and solar field (collector). The various thermodynamic parameters that were used for simulation of the overall performance of the hybrid system are shown in Table 2. Based on these boundary conditions indicated in the table, the results for the system had been analyzed.

There are various factors that affect the performance of the system, and the results are presented in this section.

3.2.1. System's Efficiency. The system efficiency is one of the most significant indexes for evaluating the characteristics and performance of the hybrid solar-geothermal ORC system technology. Two working fluids R134a and R245fa had been taken for investigation of the system performance. R134a suits well for a low-temperature heat source whereas R245fa can be used for a mediumtemperature heat source. The Carnot efficiency of the system ranged from $16 \%$ to $23 \%$ for both of the working fluids when the heat source (geothermal source) temperature lies between 70 and $99^{\circ} \mathrm{C}$. The Carnot efficiency can be increased when the heat source temperature is increased and the temperature of the heat sink is lowered. Figure 4 shows the Carnot efficiency of the proposed hybrid solar-geothermal ORC system for the particular heat source temperature.
Similarly, the thermal efficiency of the system is another indicator for measuring the system's performance. The system's thermal efficiency is a function of latent heat of evaporation, specific heat capacity, and enthalpies. The effect of thermal efficiency of the system changes with heat source temperature. The higher the heat source temperature, the higher the thermal efficiency. The rise in geothermal source temperature yields higher power output. This trend is presented in Figure 5. The maximum thermal efficiency simulated was $8.3 \%$ when the heat source was $70^{\circ} \mathrm{C}$ with the working fluid R134a. Likewise, the net power output was found to be $17.5 \mathrm{~kW}$ when the working fluid mass flow rate is $1 \mathrm{~kg} / \mathrm{s}$.

Besides, the hybrid solar-geothermal ORC source temperature changes from $70^{\circ} \mathrm{C}$ to $99^{\circ} \mathrm{C}$, and the behavior in thermal efficiency changes from $8.1 \%$ to $11.9 \%$ with the working fluid R245fa. Here, the net power output (work done) was found to be $32 \mathrm{~kW}$ when the mass flow rate of $\mathrm{R} 245 \mathrm{fa}$ was $1 \mathrm{~kg} / \mathrm{s}$. These performances on the thermal efficiency and net power output can be seen in Figure 6 .

The temperature of $99^{\circ} \mathrm{C}$ was reached when the hot spring (geothermal source) was fed into the evaluated solar collector. The hot spring temperature can be increased above the atmospheric pressure. If the system is assumed to have higher pressure for water, the performance of the system behaves differently. Figure 7 shows that the thermal efficiency of the hybrid system could reach to $15 \%$ with R245fa when the source temperature is $150^{\circ} \mathrm{C}$. This is the optimal value for the system after simulation.

3.2.2. Effect of the Pressure Ratio. The system pressure ratio determines the size, number, and type of expansion devices (expander) in the hybrid ORC technology. The higher the pressure ratio, the higher the thermal efficiency of the system. Furthermore, a higher pressure ratio system requires an increased number of expanders. In the case the system needs 


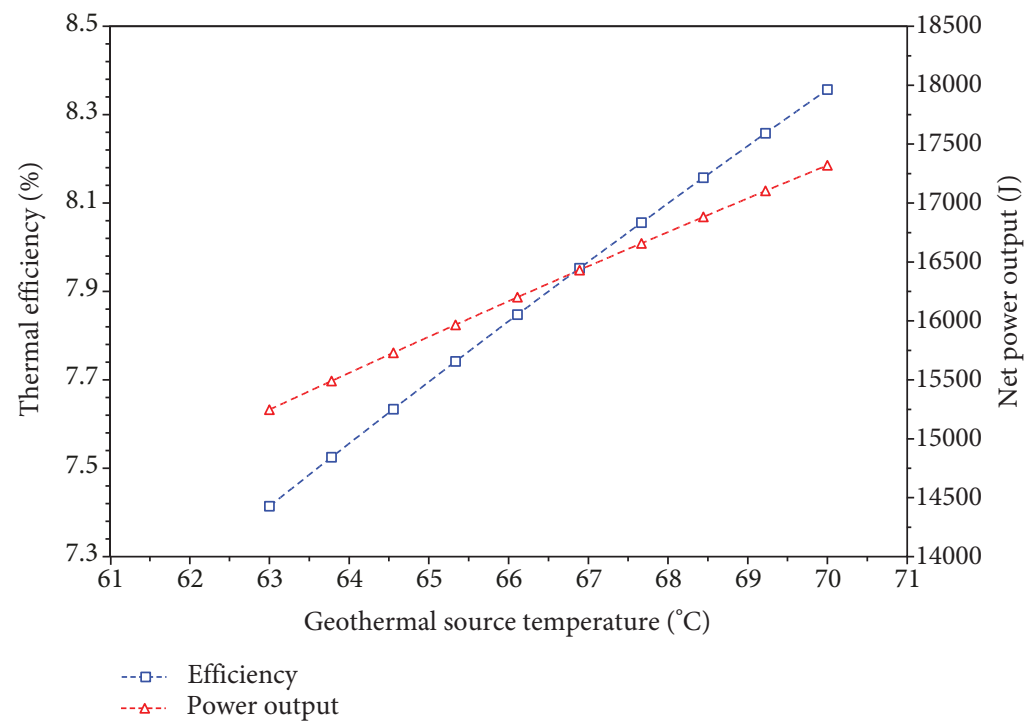

FIGURE 5: Variation of thermal efficiency and net power output with geothermal source temperature.

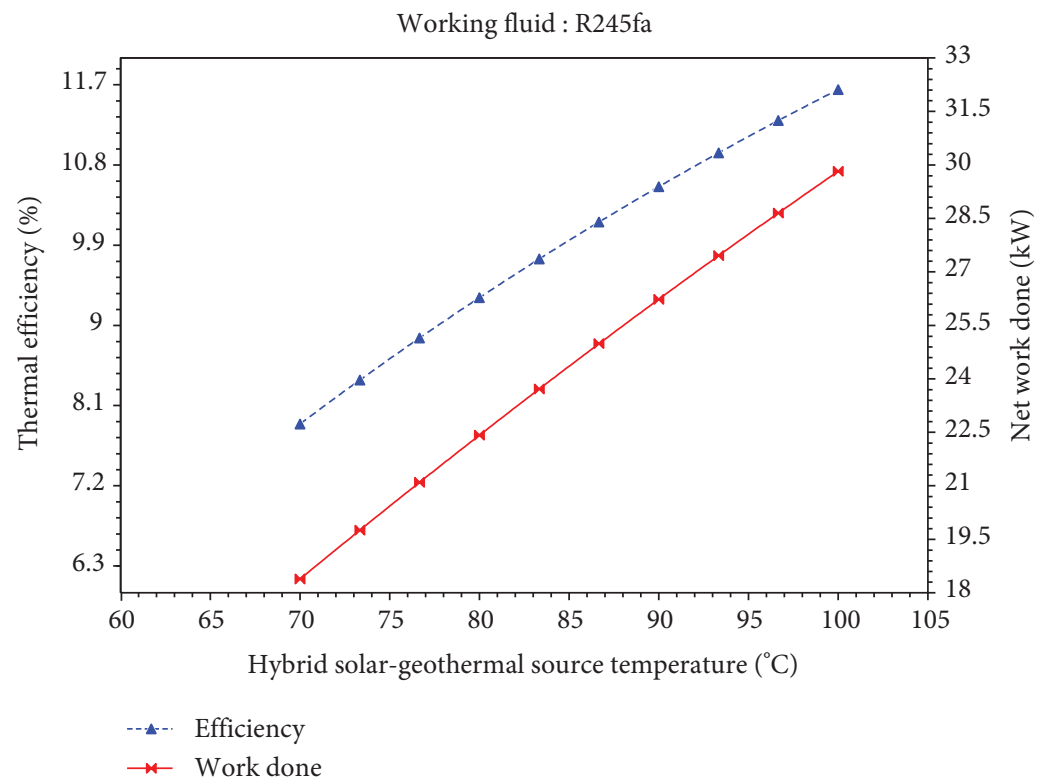

FIGURE 6: Variation of thermal efficiency and net power output with hybrid source temperature.

a higher number of expansion devices, it should be installed either in parallel or series for optimizing the performance of the system. In addition, the higher the pressure ratio, the higher the power output. Figure 8 shows that the shaft power (mechanical power) is $18.5 \mathrm{~kW}$ when the pressure ratio is 3 for the working fluid R134a. Since the pressure ratio is small, the size of the expander is small and compact.

In the same figure (Figure 8), the pump power requirement is $1.5 \mathrm{~kW}$ for running the ORC system. Similarly, for the R245fa working fluid, the pressure ratio ranged from 3.2 to 7 . Here, the shaft power obtained was $30 \mathrm{~kW}$ when the pressure ratio was 7 . The pump power input was estimated around $1.1 \mathrm{~kW}$. This scenario was observed in the simulation results as presented in Figure 9.
3.2.3. Solar Collector Sizing. The solar collector area can be best calculated based on the solar isolation of that particular location. The solar collector area can be obtained according to the turbine inlet temperature. If the turbine inlet temperature is higher, the solar ORC efficiency is higher. Figure 10 shows the effect of solar collector area requirement when the turbine inlet temperature changes. In addition, the net solar ORC efficiency can also be estimated with the collector area and the turbine inlet temperature. An area of approximately $785 \mathrm{~m}^{2}$ is required for the power output of almost $30 \mathrm{~kW}$. Similarly, the solar ORC efficiency could reach almost $9.7 \%$ when the solar collector efficiency is higher than $75 \%$. The higher the collector efficiency, the higher the solar ORC system efficiency. This 


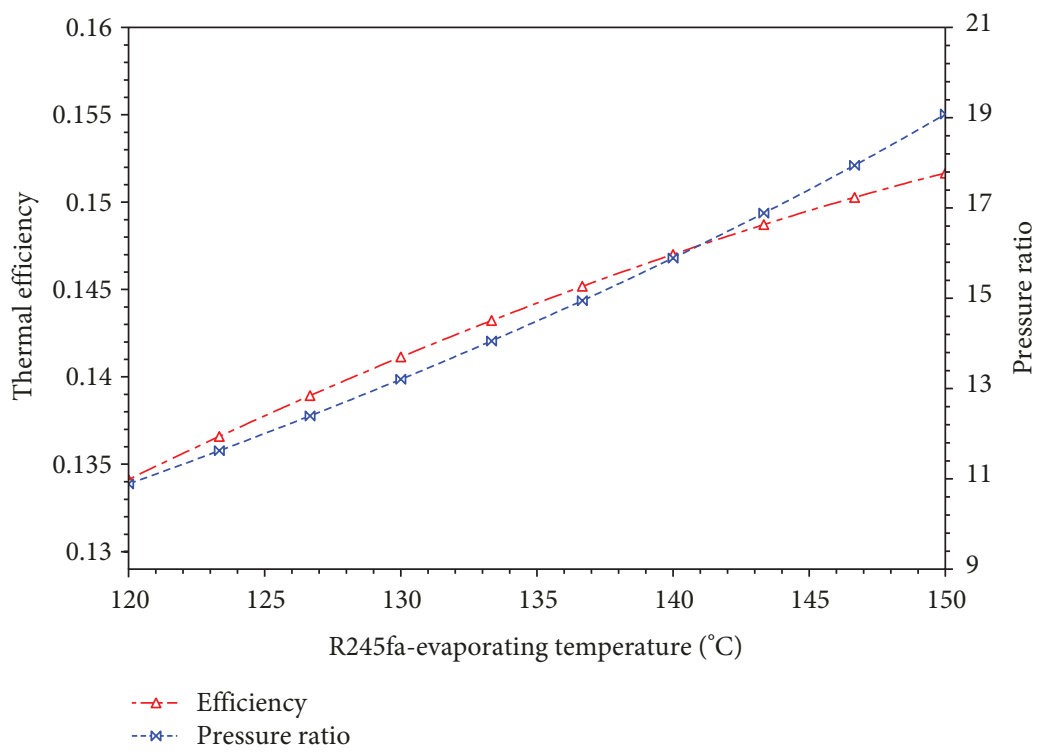

FIGURE 7: Variation of thermal efficiency and pressure ratio with hybrid solar-geothermal source temperature for R245fa.

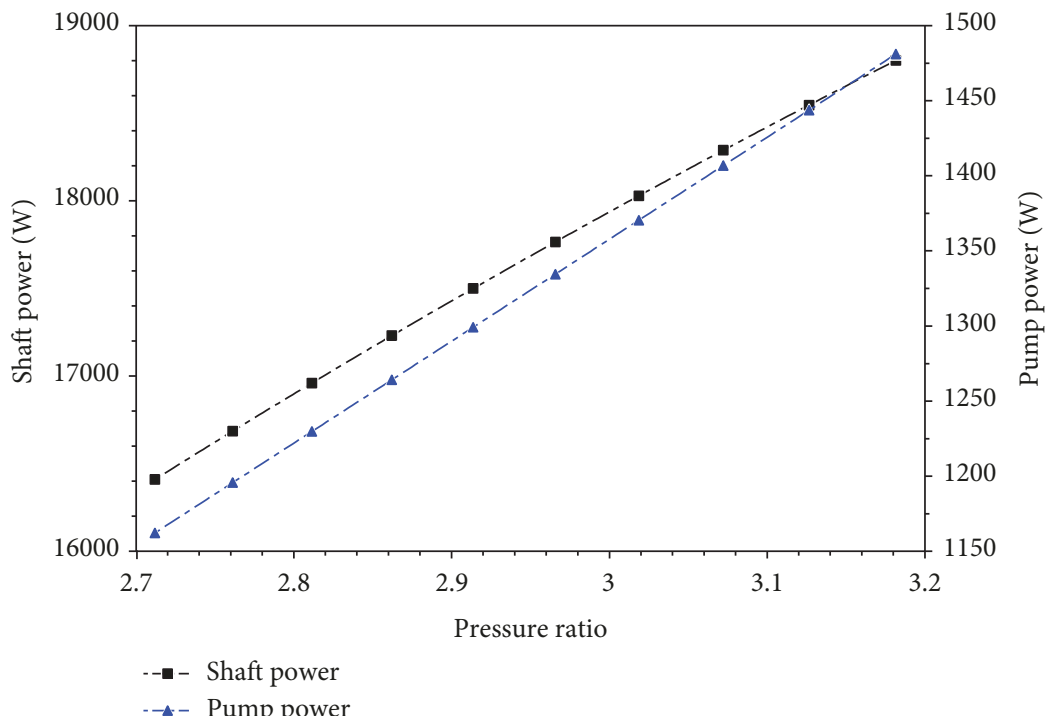

FIGURE 8: Variation of shaft power and pump input power with change in the pressure ratio (R134a).

behavior is demonstrated when the turbine inlet temperature is $145^{\circ} \mathrm{C}$ for the working fluid R245fa.

Likewise, Figure 11 shows that $267 \mathrm{~kW}$ heat is needed to produce network shaft work (mechanical work) of $40 \mathrm{~kW}$.

3.2.4. Solar ORC Power Output. The output of the solar ORC system depends mainly on the solar irradiance falling on the solar collector. The maximum solar insolation yields a high value of power output from the ORC system. The maximum solar insolation falling on the experimental site is given by an author [19]. Figure 12 shows the monthly solar ORC power output for monthly average solar irradiance falling onto the solar collectors. The maximum power output can be estimated on the month of May. During the month of May, the monthly power output was found to have $105 \mathrm{MWh}$ energy when the solar irradiance was around $430 \mathrm{~W} / \mathrm{m}^{2}$. The least power output from the system was obtained during the month of December due to low solar insolation for that particular location.

3.3. Model Validation. The developed model of the hybrid solar-geothermal organic Rankine cycle system has been validated against the previous work of references indicated in Table 3. The results of the model are very closed and showed good agreement with the referenced work. This demonstrated that the developed model is viable for the system in this study. The parameter "thermal efficiency" of the current model was varied accordingly with the references, and the 


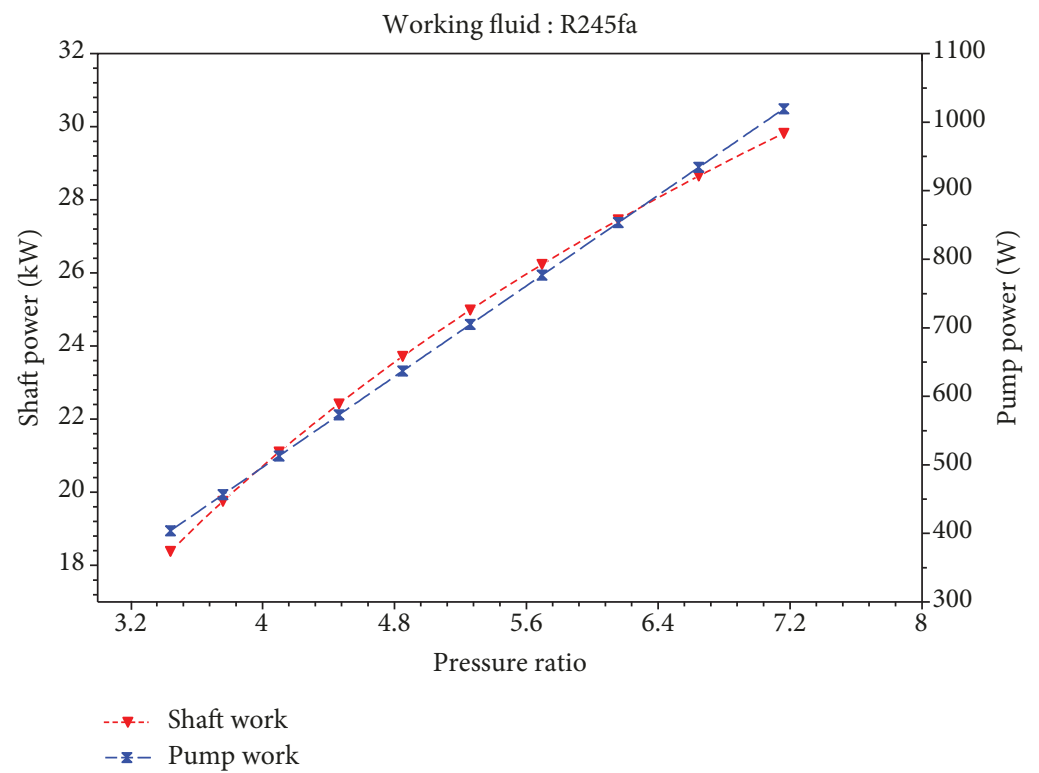

FIGURE 9: Variation of shaft power and pump input power with change in the pressure ratio (R245fa).

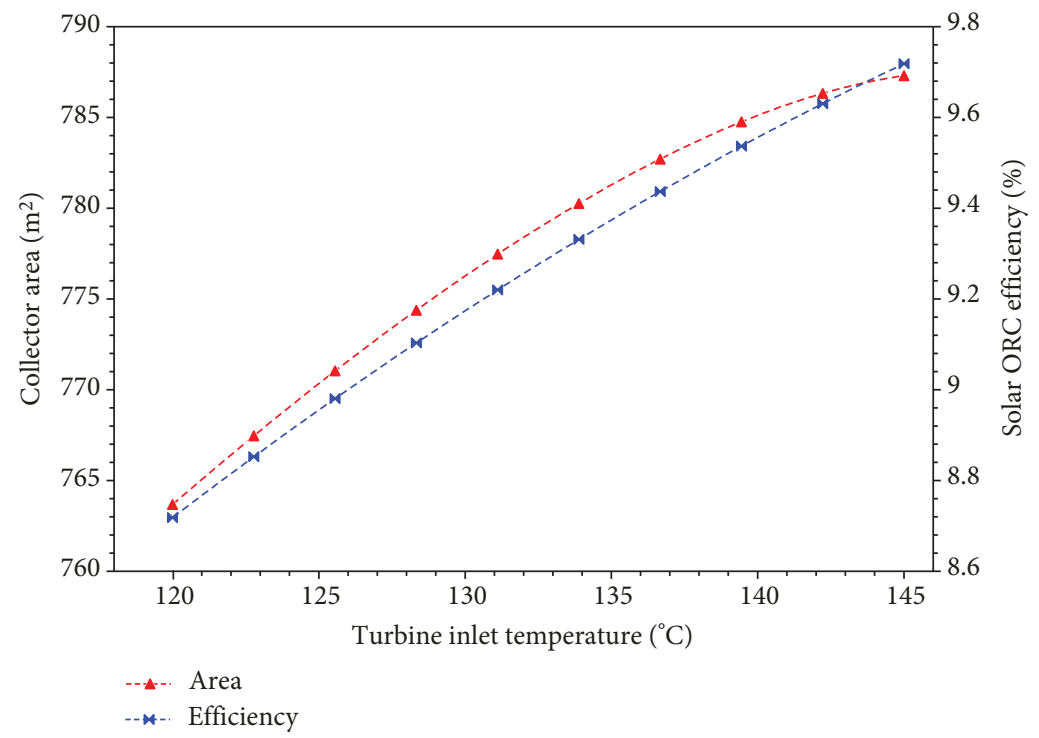

FIGURE 10: Variation of solar collector size and solar ORC efficiency with change in turbine inlet temperature (R245fa).

changes in the deviation were estimated. There are slight variations in the value obtained because several authors used different fluid property databases.

\subsection{Techno-Economic Analysis of the Hybrid Solar-} Geothermal ORC System. The techno-economic analysis was carried out in order to estimate the levelised cost of electricity generation by this technology. Furthermore, the economic indexes such as net present value (NPV), payback period (PB), internal rate of return (IRR), and sensitivity analysis were estimated to find the details of economic importance for manufacturers, investors, stakeholders, and energy planners.

The specific cost per $\mathrm{kW}$ of the hybrid solar-geothermal ORC system has been estimated by taking the reference
[20]. The individual solar ORC and geothermal ORC system-specific costs were taken into consideration. The cost of working fluids R245fa and R134a was taken on the basis of references [20]. Table 4 shows the total capital cost for the hybrid solar-geothermal ORC system. Here, the total cost of the system estimated was $\$ 30600$ for the $30 \mathrm{~kW}$ power out plant.

The maximum percentage of the share in the system is for the solar ORC unit. Due to high cost of the solar collector, this part is quiet expensive as compared to solar PV. The second highest cost share accounts for the geothermal ORC unit which is almost 25\%. During the estimation of the economic index, the component cost and operation and maintenance cost have been taken into account. It is assumed that the installation of the hybrid 


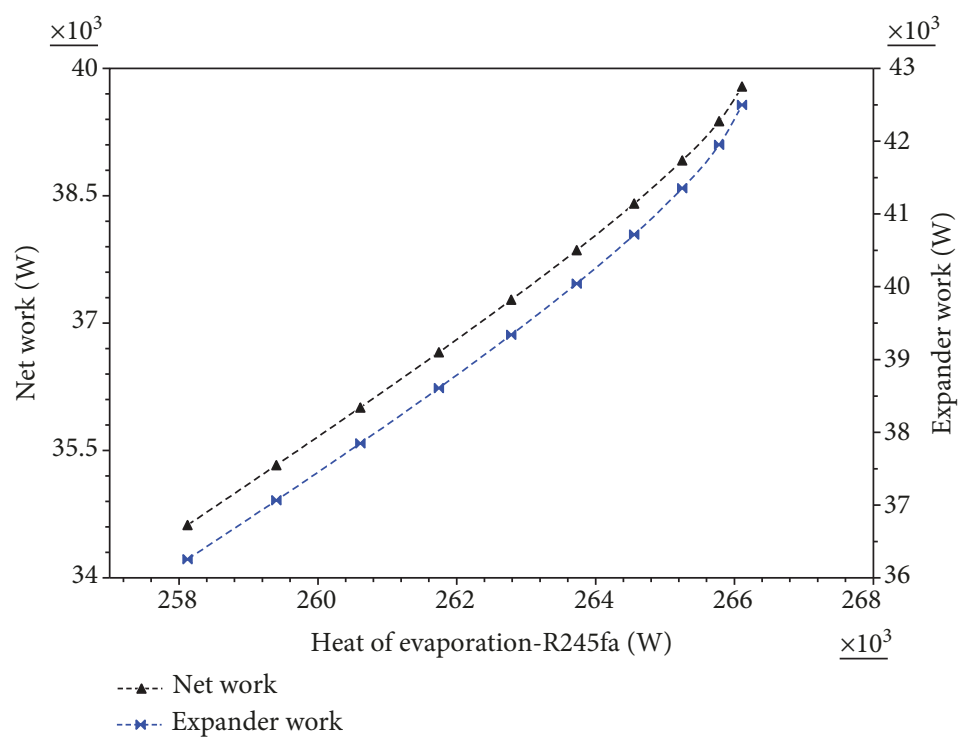

FIGURE 11: Variation of net work and expander work with change in heat of evaporation (R245fa).

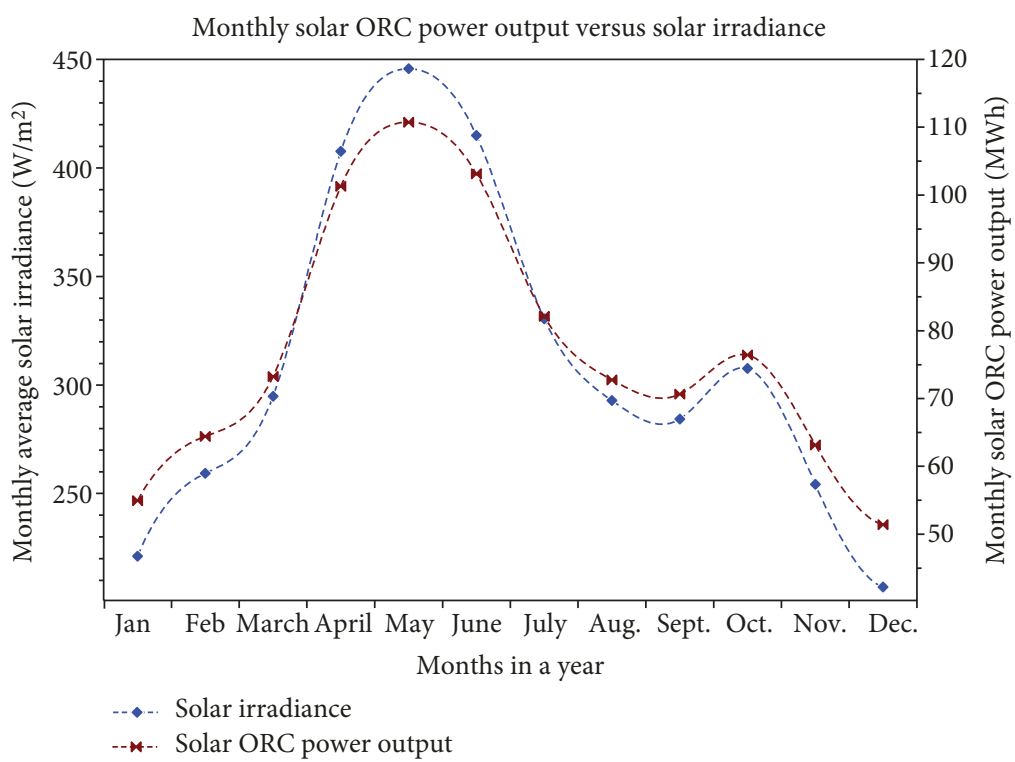

FIGURE 12: Monthly power output from the solar ORC system for different solar irradiance.

system is completed within one year. The inflation rate (interest rate) for the analysis was taken to be $5 \%$ with system life of 20 years. The salvage value for the system after 20 years is assumed to be zero. Based on these assumptions, the economic indicators were presented.

When the heat source temperature is in between 70 and $100^{\circ} \mathrm{C}$, the output power is $17.5-25 \mathrm{~kW}$ (hybrid system) with the working fluid R134a. Similarly, when the source temperature is $70-120^{\circ} \mathrm{C}$ with the working fluid R245fa, the power output was $22.5-30 \mathrm{~kW}$ (hybrid system). The annual electrical productions from the hybrid system are $139500 \mathrm{kWh}$ and $175500 \mathrm{kWh}$ for the working fluids R134a and R245fa, respectively. The costs of electricity production from the hybrid system are $\$ 0.17 / \mathrm{kWh}$ (R134a) and $\$ 0.14 / \mathrm{kWh}$ (R245fa). There is a difference of $\$ 11000$ for two different systems of the hybrid ORC plants due to their working fluids. R245fa is quiet expensive as compared to other working fluids. Table 5 shows the capital cost, annual generation cost, and cost of electrical power generation for two different working fluids.

Another economic indicator is the payback period of the installed system. The payback period is the number of years needed for the return of the investment. The payback period for the system which uses R134a is feasible when the levelised cost of electricity (LCOE) is above $\$ 0.38 / \mathrm{kWh}$. The return of investment can be achieved after 10 years of power generation. The relationship between the net cash flow and system's life is presented in Figure 13 with various LCOE.

It is seen from the analysis that the hybrid solargeothermal ORC system can be economically feasible when 
TABLE 3: Summary for validation of the referenced and current work for thermal efficiency $[13,16,22]$.

\begin{tabular}{|c|c|c|c|}
\hline Description of the system & $\begin{array}{l}\text { Thermal efficiency } \\
\text { (referenced work) }\end{array}$ & $\begin{array}{l}\text { Thermal efficiency } \\
\text { (current work) }\end{array}$ & $\begin{array}{l}\text { Percentage in } \\
\text { deviation (\%) }\end{array}$ \\
\hline $\begin{array}{l}\text { Hybridized ORC with a solar trough parallel with geothermal } \\
\text { has been analyzed; operating pressure } 2.7 \mathrm{MPa} \text { and temperature } \\
145^{\circ} \mathrm{C} \text {; DNI } 1000 \mathrm{~W} / \mathrm{m}^{2} \text {; working fluid isobutene; turbine isentropic } \\
\text { efficiency } 86 \% \text {; power output } 28 \mathrm{MW}\end{array}$ & $17.9 \%[13]$ & $19.2 \%$ & $7.26 \%$ \\
\hline $\begin{array}{l}\text { Established an experimental platform for a solar-geothermal } \\
\text { energy coupling power generation system; optimal evaporation } \\
\text { temperature } 88^{\circ} \mathrm{C} \text {; DNI } 947 \mathrm{~W} / \mathrm{m}^{2} \text {; working fluid R245fa; turbine } \\
\text { isentropic efficiency } 75 \% \text {; power output } 184.13 \mathrm{~kW}\end{array}$ & $11.21 \%[16]$ & $13.6 \%$ & $21.32 \%$ \\
\hline $\begin{array}{l}\text { Analyzed two micro-CHP systems operating with geothermal } \\
\text { and solar energy; operating temperature at } 80-100^{\circ} \mathrm{C} \text { and pressure } \\
3.1 \mathrm{MPa} \text {; DNI } 730 \mathrm{~W} / \mathrm{m}^{2} \text {; working fluid } \mathrm{R} 134 \mathrm{a} \text {; power output } 40 \mathrm{~kW}\end{array}$ & $13 \%[22]$ & $13.9 \%$ & $6.92 \%$ \\
\hline
\end{tabular}

TABLE 4: Total capital cost of the hybrid solar-geothermal ORC system.

\begin{tabular}{lccc}
\hline Parameters & Item cost $(\$)$ & Percentage of total cost (\%) & Plant economic life (years) \\
\hline Cost of building for a powerhouse & 3600 & 1.18 & 20 \\
Installation cost of the hybrid system & 2400 & 0.78 & - \\
Solar ORC system cost & 201000 & 65.69 & 20 \\
Geothermal ORC system cost & 75000 & 24.51 & 20 \\
Generators and motors & 12000 & 3.92 & 20 \\
Automatic control systems & 6000 & 1.96 & 20 \\
Miscellaneous cost & 6000 & 1.96 & - \\
Total capital cost & 306000 & 100.00 & - \\
\hline
\end{tabular}

TABLE 5: Boundary conditions for estimation for economic indices.

\begin{tabular}{lcc}
\hline Description & R134a & Working fluids \\
\hline Heat source temperature (with geothermal/with solar, $\left.{ }^{\circ} \mathrm{C}\right)$ & $70 / 100$ & $70 / 120$ \\
Power output (with geothermal/with solar, kW) & $17.5 / 25$ & $22.5 / 30$ \\
Annual electrical power generation (geothermal source only, kWh) & 94500 & 121500 \\
Annual electrical power generation (solar source only, kWh) & 45000 & 139500 \\
Annual electrical power generation (hybrid ORC, kWh) & 295000 & 175500 \\
Total cost of the hybrid ORC system $(\$)$ & 23671.56 & 306000 \\
Annual equivalent cost $(\$)$ & 0.17 & 24554.23 \\
Cost of electricity production from the hybrid ORC system $(\$ / \mathrm{kWh})$ & 0.14 \\
\hline
\end{tabular}

the LCOE is doubled with the cost of electricity production. The same pattern is seen with the working fluid R245fa as presented in Figure 14. Here, the LCOE is $\$ 0.32 / \mathrm{kWh}$ in order to have the return of investment within 11 years. But when LCOE is $\$ 0.34 / \mathrm{kWh}$, the payback period is 8 years. The payback period for the system with the working fluid R245fa has quick return due to higher energy production of electricity with the same heat source temperature.

Likewise, the benefit-cost ratio and internal rate of return (IRR) are 1.1 and $8 \%$ and 1.4 and $12 \%$ for $\mathrm{R} 134 \mathrm{a}$ and R245fa, respectively, when LCOE is $\$ 0.38 / \mathrm{kWh}$. The benefit-cost ratio is greater than 1 so it is a feasible investment. Besides, the IRR is greater than 5\% (interest rate) so it is a realistic investment.
The calculation of techno-economic analysis for the hybrid solar-geothermal ORC system has been compared with the reference work as presented in Table 6. It is illustrated that the cost of electricity production for the hybrid system was almost similar to the reference work. There are very less deviations in percentage from the calculated value. This showed that the techno-economic evaluation calculation is acceptable.

3.5. Sensitivity Analysis. Sensitivity analysis is the method for evaluating the risk associated with the investment. The sensitivity analysis is carried out by taking the most influencing parameters that play an important role in making decision whether it is worth investing or not. In the present study, 


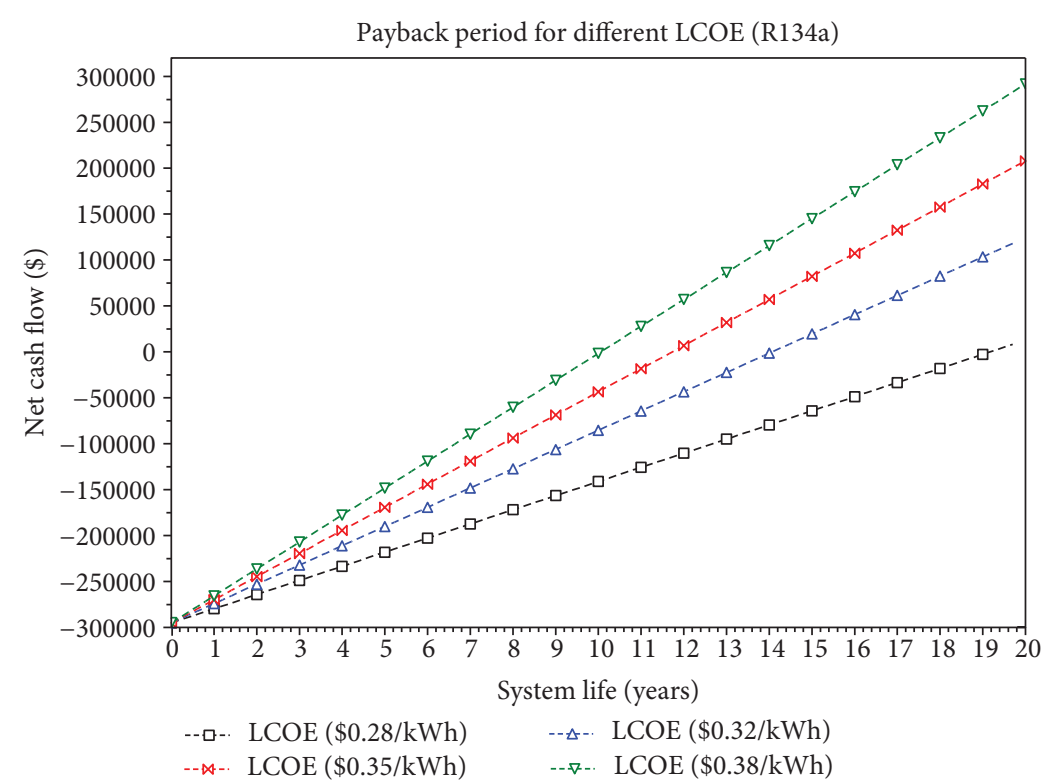

Figure 13: Net cash flow for various LCOE during the system's life period (R134a).

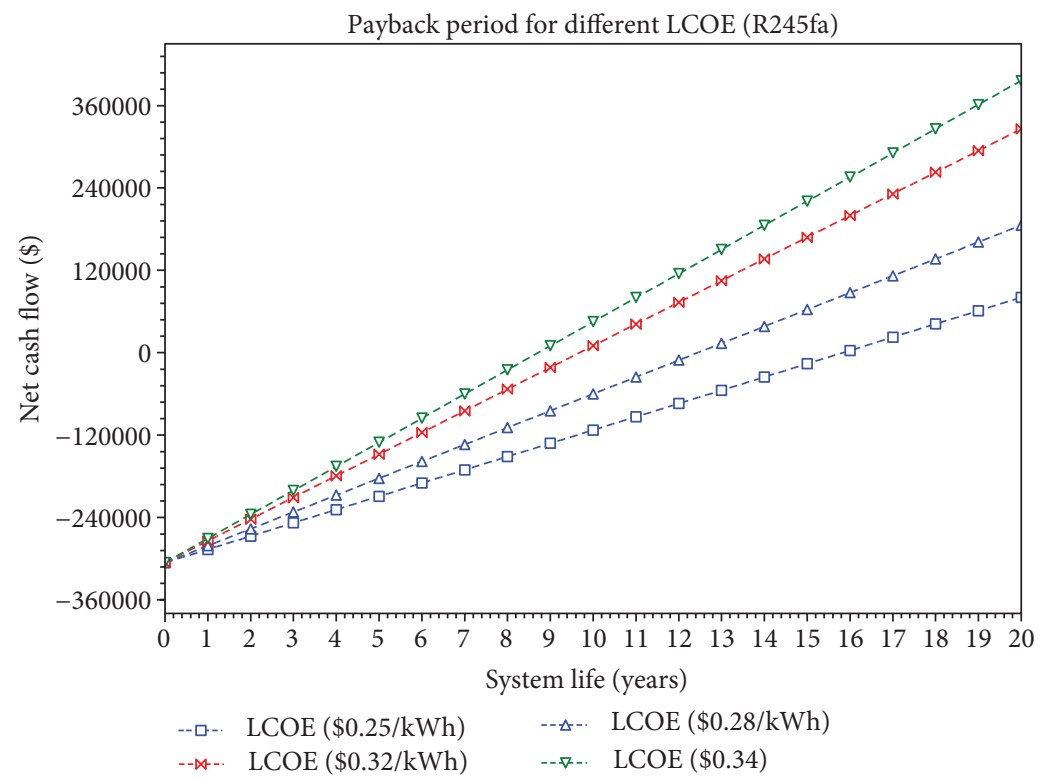

FIgURE 14: Net cash flow for various LCOE during the system's life period (R245fa).

TABLE 6: Summary for the illustration of the current work based on the referenced work for cost of electricity production.

\begin{tabular}{|c|c|c|c|}
\hline Description of the system & $\begin{array}{l}\text { Cost of electricity production } \\
\text { (referenced work) }\end{array}$ & $\begin{array}{l}\text { Cost of electricity production } \\
\text { (current work) }\end{array}$ & $\begin{array}{l}\text { Deviation } \\
(\%)\end{array}$ \\
\hline $\begin{array}{l}\text { Feasibility analysis of a medium-sized hybrid solar-geothermal } \\
\text { ORC system conducted }\end{array}$ & \$145/MWh [23] & \multirow{3}{*}{$\$ 0.14-0.17 / \mathrm{kWh}$} & $3.5 \%$ \\
\hline $\begin{array}{l}\text { Analyzed on a combined solar and geothermal binary } \\
\text { plant based on an ORC cycle system }\end{array}$ & $€ 145-280 / \mathrm{MWh}[10]$ & & $3.44 \%$ \\
\hline $\begin{array}{l}\text { Reported novel solar-geothermal polygeneration system for } \\
\text { electrical power and chilled, cooled, and desalinated water } \\
\text { production. Analyzed on exergoeconomic of the electrical } \\
\text { power production for the system }\end{array}$ & $€ 0.1475-0.1722 / \mathrm{kWh}[24]$ & & $5.08 \%$ \\
\hline
\end{tabular}


TABLE 7: Various scenarios with influencing parameters (R134a).

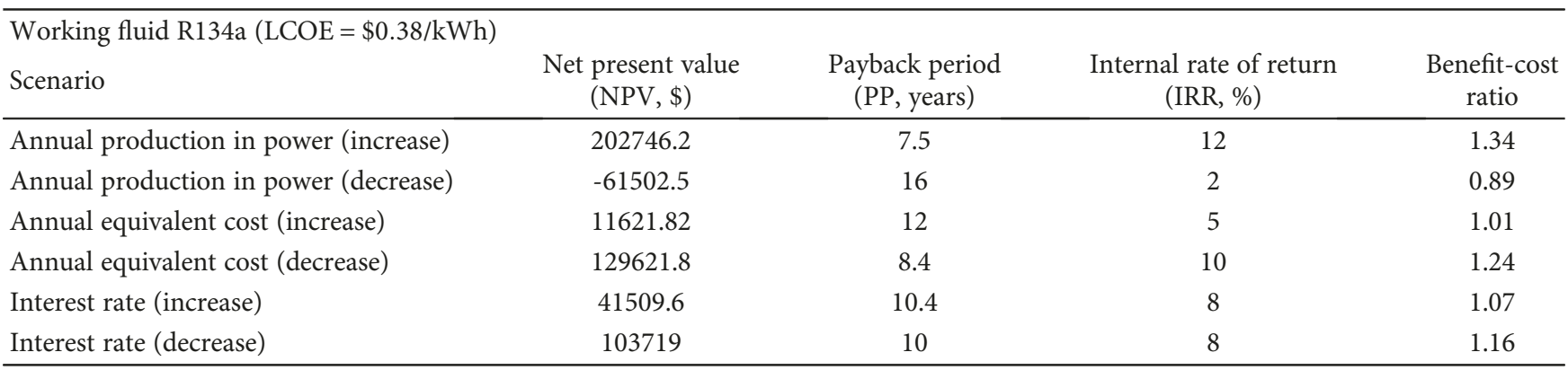

TABLE 8: Various scenarios with influencing parameters (R245fa).

\begin{tabular}{|c|c|c|c|c|}
\hline \multicolumn{5}{|l|}{ Working fluid R245fa $(\mathrm{LCOE}=\$ 0.38 / \mathrm{kWh})$} \\
\hline Scenario & $\begin{array}{c}\text { Net present value } \\
(\mathrm{NPV}, \$)\end{array}$ & $\begin{array}{c}\text { Payback period } \\
(\mathrm{PP}, \text { years })\end{array}$ & $\begin{array}{l}\text { Internal rate of } \\
\text { return (IRR, \%) }\end{array}$ & $\begin{array}{l}\text { Benefit-cost } \\
\text { ratio }\end{array}$ \\
\hline Annual production in power (increase) & 385325.8 & 5.5 & 17 & 1.62 \\
\hline Annual production in power (decrease) & 219104.8 & 7.8 & 7 & 1.08 \\
\hline Annual equivalent cost (increase) & 157904.8 & 8.9 & 11 & 1.23 \\
\hline Annual equivalent cost (decrease) & 280304.8 & 5.5 & 14 & 1.5 \\
\hline Interest rate (increase) & 177294.4 & 8 & 12 & 1.3 \\
\hline Interest rate (decrease) & 266638.4 & 7.2 & 12.4 & 1.1 \\
\hline
\end{tabular}

annual power production, annual equivalent cost, and interest rate have been chosen for the analysis. For estimating the risk, a $20 \%$ value was fluctuated from the base case. The analysis was carried out for both of the working fluids (R134a and R245fa). Since the hybrid system is only feasible when the cost of electricity production is doubled, the LCOE for the analysis was taken to be $\$ .0 .38 / \mathrm{kWh}$ for both working fluids. Table 7 shows various scenarios affecting the net present value (NPV) with a $20 \%$ change in its influencing parameters.

The sensitivity analysis indicates that when the annual production power is increased by $20 \%$, the payback period is only 7.5 years with IRR of $12 \%$. The net present value for this hybrid system is $\$ 202746.2$ with a benefit-cost ratio of 1.34. The possibility of increment in annual production is running the ORC system for all hours throughout the year. This analysis was estimated for the working fluid R134a when the LCOE is $\$ 0.38 / \mathrm{kWh}$.

A similar pattern is seen for the working fluid R245fa, when there is an annual power production increment from the hybrid. The results of the sensitivity analysis can be observed from Table 8 . Here, the payback period is only 5.5 years which seems very feasible investment. The IRR and benefit-cost ratio are $17 \%$ and 1.62 , respectively.

In Figures 15 and 16, the variation of the net present value (NPV) for all three different scenarios was examined and illustrated the importance of influencing parameters for the hybrid solar-geothermal ORC system. The highest dependency of NPV is for annual production of power followed by annual equivalent cost for both of the working fluids. The NPV should be positive in order to be feasibly invested. Figure 15 shows a slightly curvature type of profile; this is due to the negative NPV for the system.

\section{Conclusions}

The study reported the feasibility analysis of the stand-alone hybrid solar-geothermal organic Rankine cycle technology for power generation in Bhurung Tatopani, Myagdi. The experiment conducted on the Tatopani site revealed the temperature of the hot spring to be $69.7^{\circ} \mathrm{C}$. Another experiment included feeding of the hot spring into the solar collector in order to observe the temperature increment which can be applied in the developed model. In the experimental results, it was illustrated that the temperature could reach $99^{\circ} \mathrm{C}$. The thermodynamic models were developed from the governing equations of ORC system components. The model was developed by Engineering Equation Solver (EES). The developed model predicted the performance of the system when the input parameters were given. The simulation results showed that two different working fluids R134a and R245fa behave differently when the heat source temperature changes from $70-120^{\circ} \mathrm{C}$. The power output from the system was $17.5 \mathrm{~kW}$ with $1 \mathrm{~kg} / \mathrm{s}$ mass flow rate of the working fluid $\mathrm{R} 134 \mathrm{a}$ in heat temperature of $70^{\circ} \mathrm{C}$. The power output increased to $25 \mathrm{~kW}$ when the hot spring being heated with the solar collector reached the temperature of $99^{\circ} \mathrm{C}$. The thermal efficiency was found to be around $8 \%$. Similarly, for the working fluid R245fa, when the source temperature was $70^{\circ} \mathrm{C}$, the output power was $22.5 \mathrm{~kW}$. The thermal efficiency was found to be $10 \%$. It was concluded that the working fluid R245fa could get higher power output due to its 


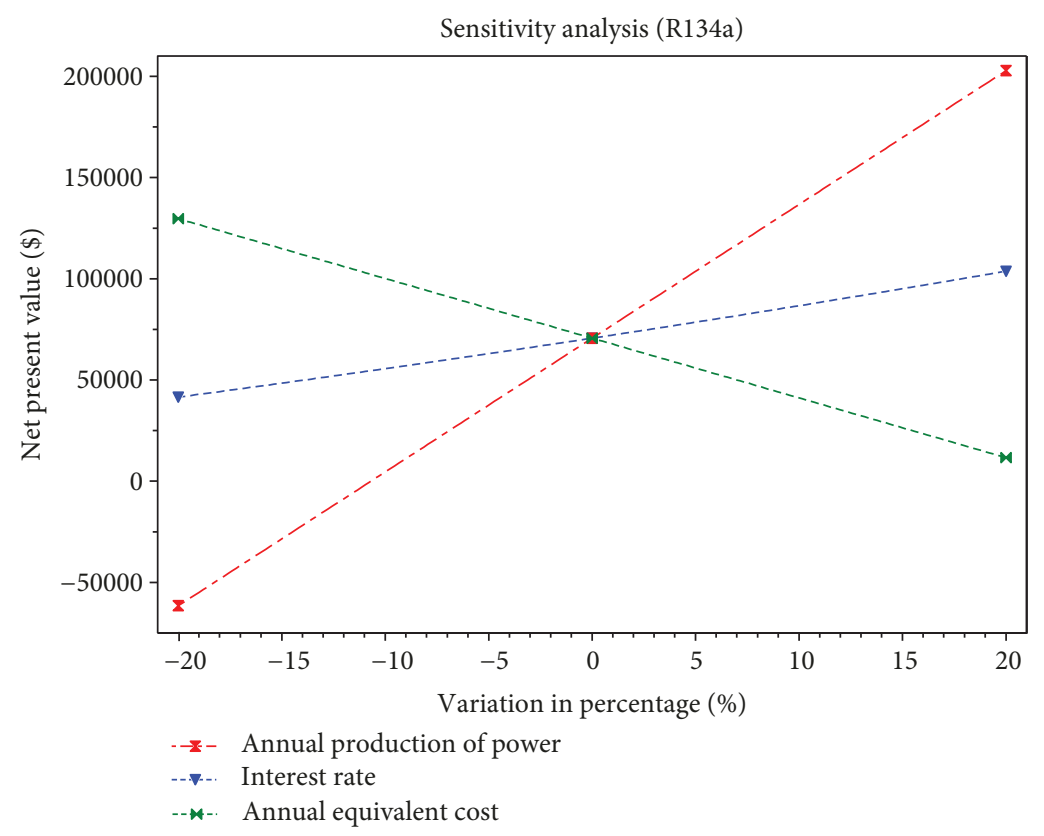

FIGURE 15: Variation of NPV for different influencing economic parameters (R134a).

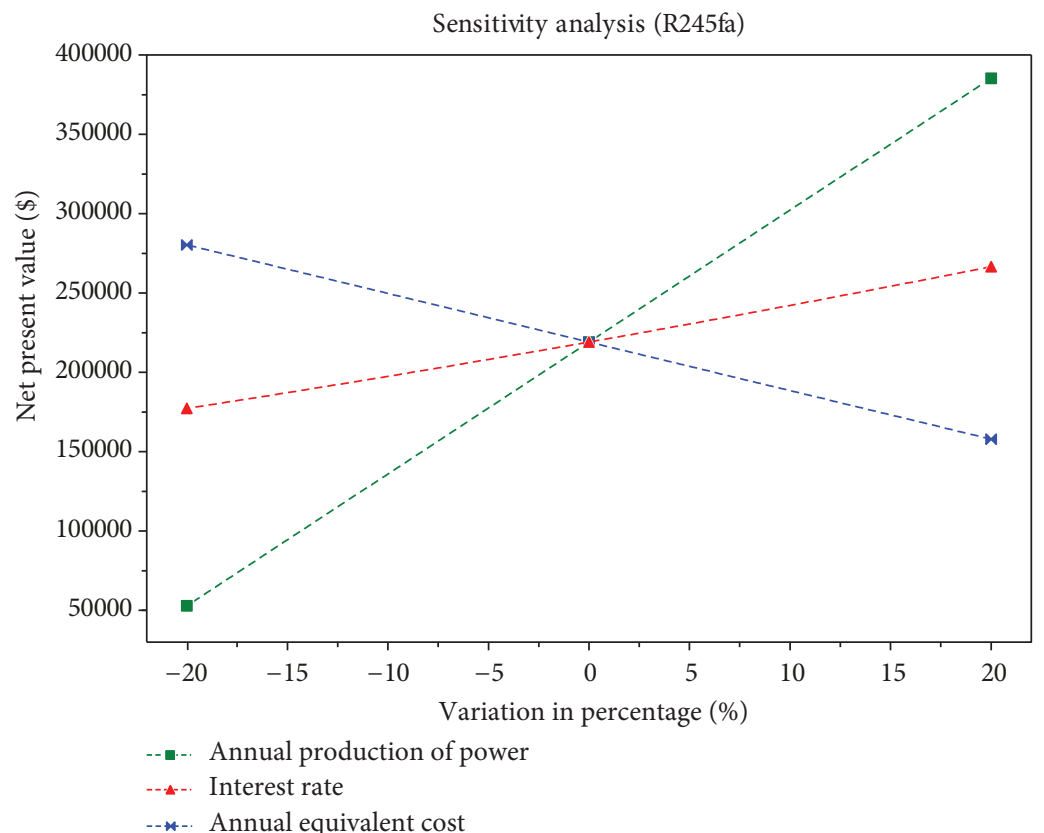

FIGURE 16: Variation of NPV for different influencing economic parameters (R245fa).

thermo-physical characteristics when subjected to various temperature values. In another part of the study, the techno-economic analysis was conducted for the hybrid system. The analysis was carried out for the power output of $30 \mathrm{~kW}$. The analyzed results indicated that the cost of electricity production is $\$ 0.17 / \mathrm{kWh}$ for $\mathrm{R} 134 \mathrm{a}$ and $\$ 0.14 / \mathrm{kWh}$ for R245fa. The payback period, benefit-cost ratio, and IRR are 12 years, 1.34 , and $12 \%$ and 5.5 years, 1.62 , and $17 \%$ for R134a and R245fa, respectively. For both cases, LCOE was
$\$ 0.38 / \mathrm{kWh}$. Therefore, the key finding is that the standalone hybrid solar-geothermal ORC system is feasible for power generation and is economically viable.

\section{Data Availability}

The data used to support the findings of this study are available from the corresponding author upon request. 


\section{Conflicts of Interest}

The author declares that there are no conflicts of interest.

\section{Acknowledgments}

This research was funded by the University Grants Commission, Nepal, as part of a Small Research, Development and Innovation Grant (2073-74) awarded to Dr. Suresh Baral. The funding grant number is 073/074-engg-05.

\section{References}

[1] International Energy Agency, Market Report Series: Energy Efficiency, International Energy Agency, 2018, https:// webstore.iea.org/market-report-series-energy-efficiency-2018.

[2] R. Bhandari and I. Stadler, "Electrification using solar photovoltaic systems in Nepal," Applied Energy, vol. 88, no. 2, pp. 458-465, 2011.

[3] K. N. Poudyal, B. K. Bhattarai, B. Sapkota, and B. Kjeldstad, "Estimation of global solar radiation using clearness index and cloud transmittance factor at trans-Himalayan region in Nepal," Energy and Power Engineering, vol. 4, no. 6, pp. 415421, 2012.

[4] S. Baral and K. C. Kim, "Existing and recommended renewable energy conversion technologies for electricity generation in Nepal," South Asia, vol. 68, p. 493, 2014.

[5] S. Quoilin, M. Orosz, H. Hemond, and V. Lemort, "Performance and design optimization of a low-cost solar organic Rankine cycle for remote power generation," Solar Energy, vol. 85, no. 5, pp. 955-966, 2011.

[6] M. Orosz, Small scale solar ORC system for distributed power in Lesotho, Solar World Congress, Johannesburg, South Africa, 2009.

[7] M. Ranjit, "Geothermal energy update of Nepal," in Proceedings of the World Geothermal Congress, Turkey, 2005.

[8] M. Ranjit, "Preliminary evaluation of geothermal reservoir in Central Nepal using geochemical data," in Proc. World Geothermal Congress, Bali, Indonesia, 2010.

[9] F. Heberle, M. Preißinger, and D. Brüggemann, "Zeotropic mixtures as working fluids in organic Rankine cycles for lowenthalpy geothermal resources," Renewable Energy, vol. 37, no. 1, pp. 364-370, 2012.

[10] M. Astolfi, L. Xodo, M. C. Romano, and E. Macchi, “Technical and economical analysis of a solar-geothermal hybrid plant based on an organic Rankine cycle," Geothermics, vol. 40, no. 1, pp. 58-68, 2011.

[11] G. Shu, G. Yu, H. Tian, H. Wei, X. Liang, and Z. Huang, "Multi-approach evaluations of a cascade-organic Rankine cycle (C-ORC) system driven by diesel engine waste heat: part A-thermodynamic evaluations," Energy Conversion and Management, vol. 108, pp. 579-595, 2016.

[12] G. Yu, G. Shu, H. Tian, H. Wei, and X. Liang, "Multi-approach evaluations of a cascade-organic Rankine cycle (C-ORC) system driven by diesel engine waste heat: part B-technoeconomic evaluations," Energy Conversion and Management, vol. 108, pp. 596-608, 2016.

[13] H. Ghasemi, E. Sheu, A. Tizzanini, M. Paci, and A. Mitsos, "Hybrid solar-geothermal power generation: optimal retrofitting," Applied Energy, vol. 131, pp. 158-170, 2014.
[14] M. Ciani Bassetti, D. Consoli, G. Manente, and A. Lazzaretto, "Design and off-design models of a hybrid geothermal-solar power plant enhanced by a thermal storage," Renewable Energy, vol. 128, pp. 460-472, 2018.

[15] M. Ayub, A. Mitsos, and H. Ghasemi, "Thermo-economic analysis of a hybrid solar-binary geothermal power plant," Energy, vol. 87, pp. 326-335, 2015.

[16] A. Song, J. Zhu, P. Zhang, N. Chang, and Z. Cui, "Experimental research on solar and geothermal energy coupling power generation system," Energy Procedia, vol. 158, pp. 59825987, 2019.

[17] Y. A. Cengel and M. A. Boles, "Thermodynamics: An Engineering Approach," Sea, vol. 1000, article 8862, 2002.

[18] S. A. Kalogirou, Solar Energy Engineering: Processes and Systems, Academic Press, 2013.

[19] S. Adhikari, "Seasonal and spatial variation of solar radiation in Nepal Himalayas," Journal of Hydrology and Meteorology, vol. 8, no. 1, pp. 1-9, 2016.

[20] S. Lemmens, "Cost engineering techniques and their applicability for cost estimation of organic Rankine cycle systems," Energies, vol. 9, no. 7, p. 485, 2016.

[21] S. Baral, D. Kim, E. Yun, and K. Kim, "Experimental and thermoeconomic analysis of small-scale solar organic Rankine cycle (SORC) system," Entropy, vol. 17, no. 4, pp. 2039-2061, 2015.

[22] D. Tempesti, G. Manfrida, and D. Fiaschi, "Thermodynamic analysis of two micro CHP systems operating with geothermal and solar energy," Applied Energy, vol. 97, pp. 609-617, 2012.

[23] F. Heberle, M. Hofer, N. Ürlings, H. Schröder, T. Anderlohr, and D. Brüggemann, "Techno-economic analysis of a solar thermal retrofit for an air-cooled geothermal organic Rankine cycle power plant," Renewable Energy, vol. 113, pp. 494-502, 2017.

[24] F. Calise, M. D. d'Accadia, A. Macaluso, A. Piacentino, and L. Vanoli, "Exergetic and exergoeconomic analysis of a novel hybrid solar-geothermal polygeneration system producing energy and water," Energy Conversion and Management, vol. 115, pp. 200-220, 2016. 

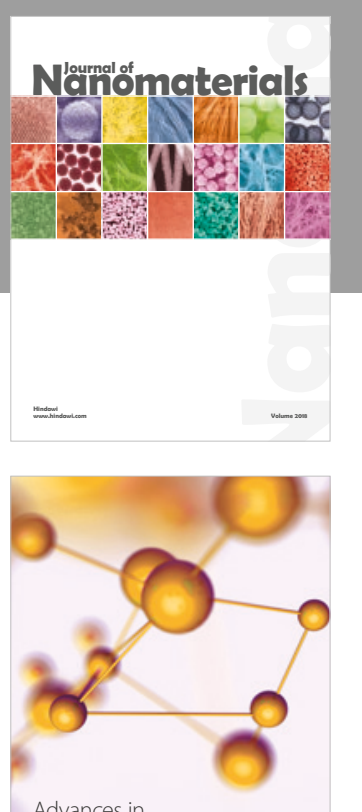

Physical Chemistry
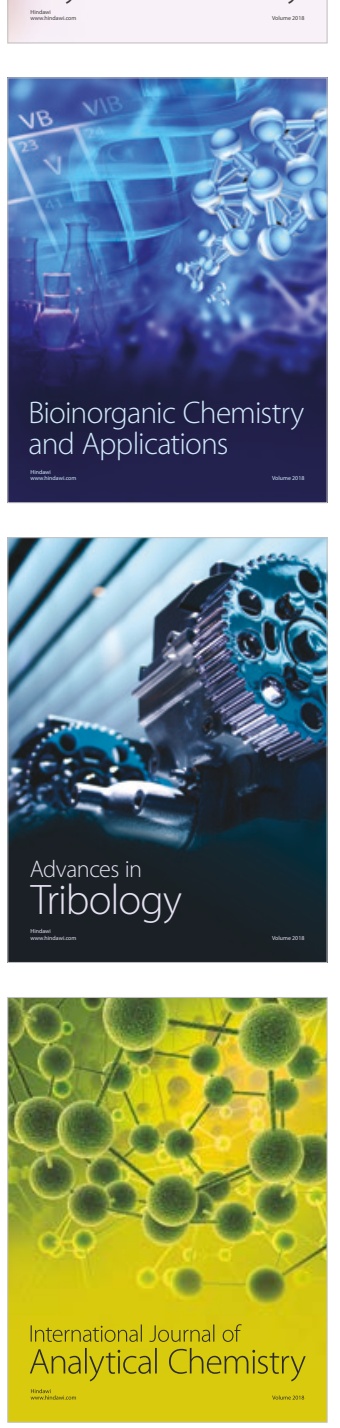

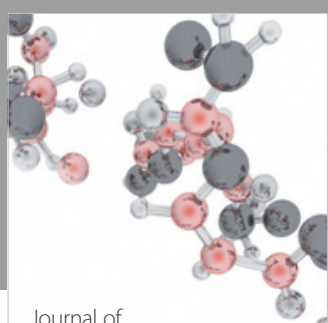

Analytical Methods

in Chemistry

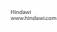

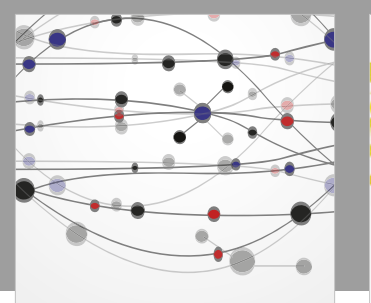

The Scientific World Journal

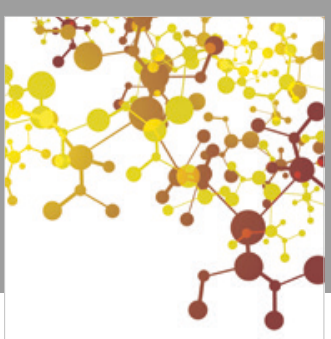

Journal of

Applied Chemistry
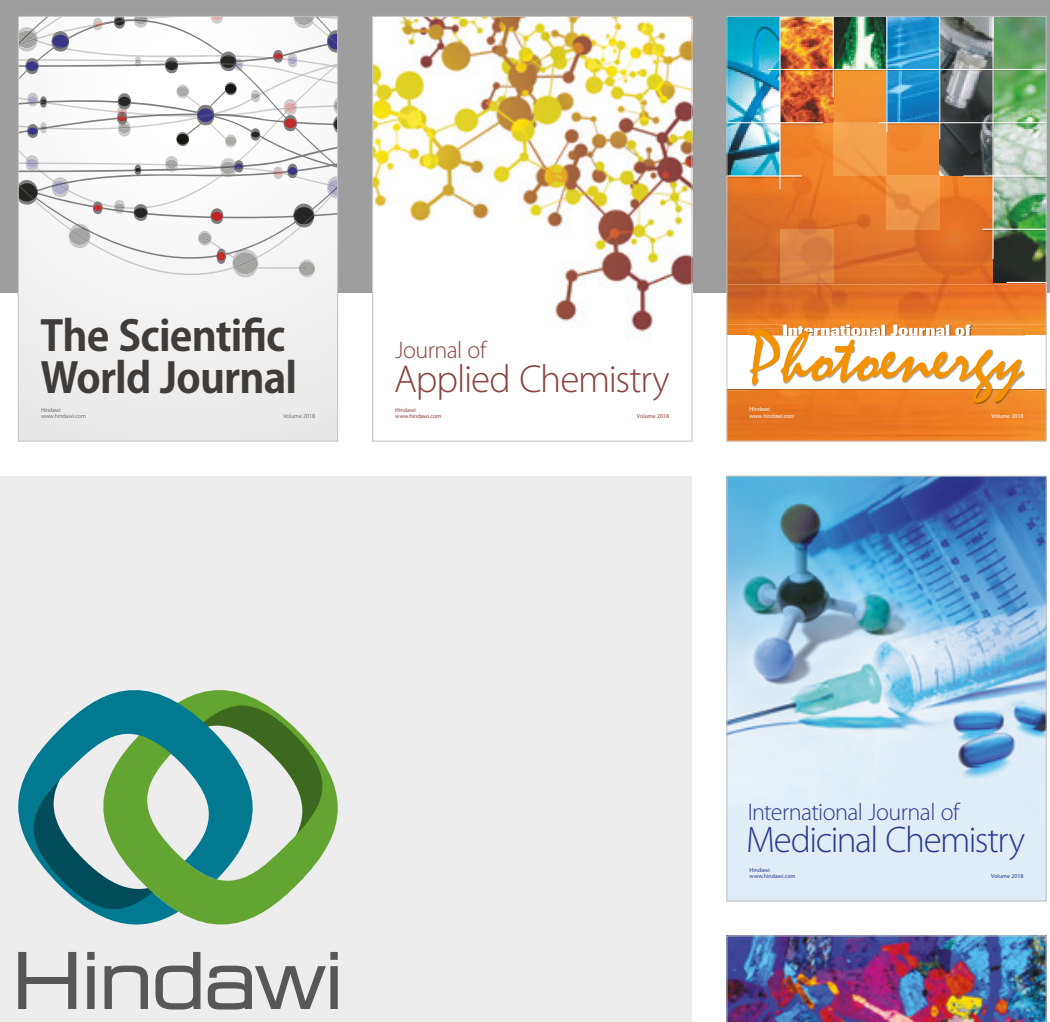

Submit your manuscripts at

www.hindawi.com
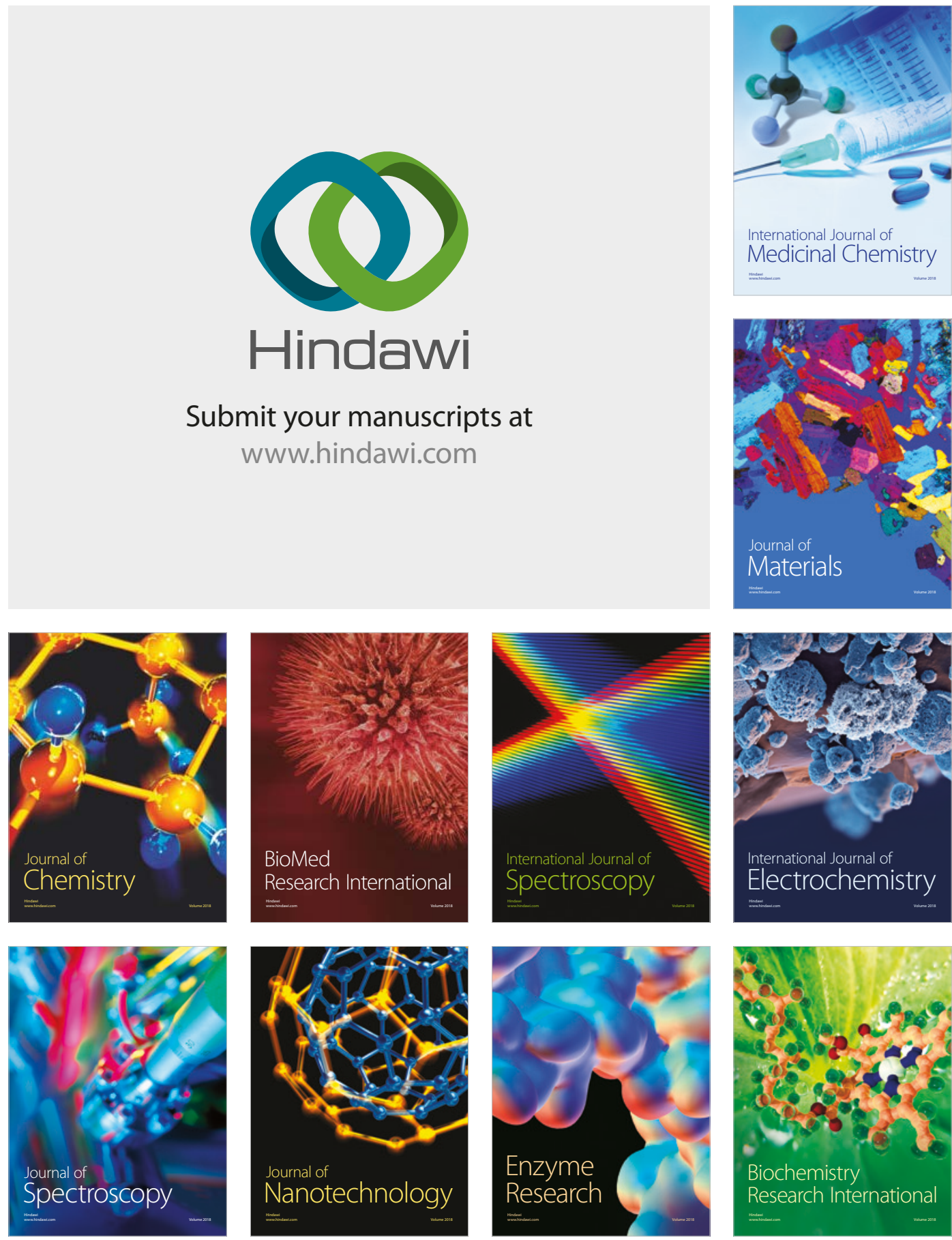
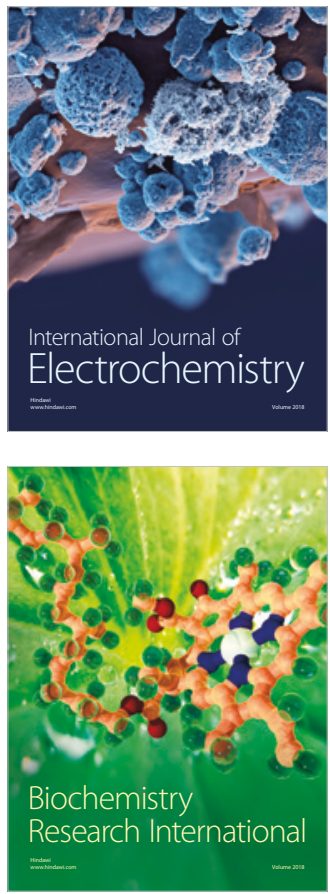